\title{
Featuring of Islam in the writings, particularly Old Testament commentaries, of Adrianus Van Selms (1906-1984)
}

\author{
M.A.E (ASHRAF) DOCKRAT \\ (LANCSAL, UNIVERSITY OF JOHANNESBURG, SOUTH AFRICA) \\ ABSTRACT
}

\begin{abstract}
Adrianus van Selms is well known for especially two studies related to Islam, viz. a Muslim Catechism (1951) and a publication entitled 'Abu Bakr's Exposition of the Religion' (1979). Both feature Afrikaans texts, dating from the second half of the 19th century, written in Arabic letters for the benefit of the local population.
\end{abstract}

Van Selms, furthermore, contributed to an Afrikaans publication with the title In Gesprek met Islam oor die Moslem Belydenis [In Conversation with Islam as regards the Muslim Confession of Faith] (1974), providing an elaborate discussion with respect to Islam against the background of the Old and New Testaments and Church History. Van Selms, inter alia, opined, "For reasons concealed from us, it pleased God to chastise his church with Muslims' words and conduct." Similar statements are found in 8th and 9th century Christian polemical texts (cf. Griffiths 2008).

In his books focusing on Jerusalem and Northern Israel, Van Selms (1967) expresses his appreciation for the Muslim material culture, and customs related to those practised in Old and New Testament times.

For the purpose of the present paper, however, attention will specifically be given to the contextualisation of references to Islam in Van Selms' biblical commentaries, for example the mentioning of a tradition recounted by al-Tabari (839-923 CE) during the exposition of Gen 3:1; a comparison of Muslim and biblical rules of marital conduct (Ex 21:21) that come to the fore in Gen 30:14-6; and finally the parallels drawn between the religious exclusivity evident in Ezra 10:11 and the Muslim concept of ummah.

KEYWORDS: Van Selms, Islam and Christianity in South Africa, Arabic-Afrikaans, Genesis, Ezra

Submitted: 24/07/2019; peer-reviewed: 03/03/2020; accepted: 05/03/2020. M.A.E (Ashraf) Dockrat, "Featuring of Islam in the writings, particularly Old Testament commentaries, of Adrianus Van Selms (1906-1984)," Old Testament Essays 33 no. 1 (2020): 60 - 79. DOI: https://doi.org/10.17159/2312-3621/2020/v33n1a5. 


\section{A INTRODUCTION}

The theme of 2017's OTSSA / OTWSA congress was "Six Decades of Old Testament Scholarship in South Africa and Beyond", inviting reflection on scholars and their contribution since the founding of the society in 1957. Among them should be mentioned the name of Adrianus Van Selms (1906-1984), an acknowledged authority on the Old Testament and Semitic Languages. His literary output has not gone unnoticed, be it in books ${ }^{1}$ or lectures ${ }^{2}$. However, it would seem as if his contributions pertaining to Islam, particularly within the context of the Old Testament, have been neglected. This paper is devoted to a study of this aspect of his work, focusing on a few selected examples.

Topics to be dealt with are Van Selms' contribution to books pertaining to Islam, his responses to Muslim culture, and finally references to Islam in Van Selms' Biblical commentaries. This, in order to inform, identify theological tendencies and to contextualise Van Selms' views.

\section{B CONTRIBUTION TO BOOKS PERTAINING TO ISLAM}

Adrianus van Selms is known especially for two studies related to Islam. They are a bilingual (Arabic and Afrikaans) Muslim catechism (1951) and an exposition of the religion (1979). Both feature Afrikaans texts, dating from the second half of the $19^{\text {th }}$ century, written in Arabic letters for the benefit of the local population. However, Van Selms (1974) also coedited a study featuring a Christian perspective on aspects of Muslims' confession of faith. ${ }^{3}$

The most elaborate work by Van Selms pertaining to Islam is the 1979 publication of an Arabic-Afrikaans text ${ }^{4}$ from the year 1869, containing Abu Bakr Effendi's exposition of aspects of the Muslim religion. It consists of an introduction, followed by 218 pages in which a transliteration of the ArabicAfrikaans text is given side by side with a rather literal Afrikaans translation. The transliteration and transcription keep close to the source text, giving no indication (as in the original version) of the different sections and subsections, elucidating prescribed Muslim customs as regards ritual purification, șalāt

1 E.g. Jurie H. le Roux. A Story of Two Ways, Thirty Years of Old Testament Scholarship in South Africa (Pretoria: Verba Vitae, 1993).

2 Cf. James A. Loader, 1995. “Adrianus Van Selms: responsum”, JSem 7(1995):240-250; and J F (Hans) Janse van Rensburg. "Adrianus Van Selms (19061984): What does abide. Aspects of his life and literary contribution", JSem 26/1 (2017):504-545.

3 Adrianus Van Selms. Arabies-Afrikaanse Studies 1. 'n Tweetalige (Arabiese en Afrikaanse) Kategismus, 1979)

4 The term, coined by Van Selms, characterized a text featuring Afrikaans written (with some adaptations) in Arabic script. 
(prayer), zakāt (alms tax), șaum (fasting), slaughtering of animals, religious restrictions, what is permitted to drink, and hunting.

Furthermore, Van Selms provides a register at the end of the work consisting of a selection of words written in standard Afrikaans followed by the different ways in which they are transliterated in the manuscript. As regards a detailed discussion of the work as well as an English translation, Van Selms refers to the 1960 study of Mia Brandel-Syrier, to which he (Van Selms) himself made a contribution. ${ }^{5}$

For the purpose of the present paper, note need only be taken of the brief introduction. In this Van Selms focuses on the writer, the book itself (particularly its preliminary observations), the method of publication, and its objective. As regards the latter aspect, Van Selms emphasises the value of the manuscript for the study of early Afrikaans. He warns against using the book to ridicule Islam, stating that what is discussed by Abu Bakr [Effendi] is only part of the teachings of Islam. Even so, the prescriptions given are of great importance for Muslim believers. ${ }^{6}$ The attitude of respect that is asked for is a characteristic of Van Selms whenever any aspect pertaining to Islam comes to the fore.

An earlier 1951 study of Van Selms, an Arabic-Afrikaans Muslim catechism transcribed in standard Afrikaans, covers by means of the technique of question and answer (su'āl wa-jawāb) some of the main features of Islamic religious teaching, e.g. God (Allah), Messengers, Revelatory Books, Angels and the Hereafter.

Van Selms provides some background information ${ }^{7}$ to the question-andanswer genre According to him, it is a genre commonly used, the objective being that the teacher asks the questions, and the pupil answers. Van Selms expresses the conviction that the origin of the system of asking questions and expecting answers, which is found both in Christianity and Islam, can be traced back to ancient Judaism which in turn can be related to oracles in the SumerianBabylonian religion, where questions pertaining to the future and the correct conduct were put to the sun-god Marduk. Old Testament parallels are cited by Van Selms, such as when David asked for the priestly shoulder-garment, and questioned God about the outcome of future military expeditions of King Saul (1 Samuel 23:9-12), and of his own (1 Samuel 30:8). Furthermore, reference is made to Haggai 2:11-13, where the prophet seeks clarification from the priest

5 Adrianus Van Selms, "The manuscript and its author", in The Religious Duties of Islam as Taught and Explained by Abu Bakr Effendi. A Translation from the Original Arabic And Afrikaans, Edited with An Introduction and Notes, ed. Mia Brandel-Syrier (Pretoria Oriental Series 11, Leiden: Brill, 1960), v-ix

6 Van Selms, Adrianus.'n Tweetalige (Arabiese en Afrikaanse) Kategismus (Amsterdam: N.V. Noord-Hollandsche Uitgevers Maatschappij, 1951).

7 Van Selms, Tweetalige (Arabiese en Afrikaanse) Kategismus. 25-31 
about cultic matters (regarding sacrificial meat), and Malachi 2:6-7 where people are admonished to seek instruction (tōrāh) from the priest "because he is the messenger ( $m a l$ ' $a k$ ) of the Lord Almighty". Concerning later Jewish tradition, Van Selms draws attention to the custom of questions and answers in the Mishna, Talmud and related literature. He notes specifically the custom of numbering proverbs found in the tractate "Sayings of the Fathers". The latter aspect is not pursued further, but it is noteworthy that $s u$ 'a $l w a-j a w a \bar{a} b$ (question and answer) comprises 80 questions and answers. Van Selms also mentions a few Arabic catechism examples, regretting that due to his distance (South Africa) from the centre of Arabic studies, he was not able to compare the catechism with similar works. ${ }^{8}$

The Babylonian-Assyrian parallels cited by Van Selms are informative, but whether a catechism teaching Muslims the basic aspects of their religion needs to be traced to ancient cultic contexts is debatable. Questions, which in fact introduce topics, followed by ideal answers highlighting main aspects of the topic are a common feature in teaching. In the Christian context attention may be drawn to the Heidelberg catechism (1563) with its 53 questions and answers9.

Van Selms furthermore contributed to a study featuring a "Conversation with Islam as regards the Muslim Confession of Faith". In it he provides an elaborate discussion with respect to Islam against the background of the Old and New Testament and Church History. Special attention is given to the concept of "prophecy" in general and within the different religious contexts, including the Old and New Testament as well as Islam. Within the Old Testament environment ${ }^{10}$ Van Selms distinguishes between true and false prophecy. As regards the New Testament ${ }^{11}$ attention is drawn to Luke 13:19 where the two men on their way to Emmaus referred to Jesus of Nazareth as "a prophet, powerful in word and deed before God and the people". Van Selms opines that the essential feature that distinguishes the prophetic activity of Jesus from others is that he was not only the transmitter ("oorbrenger") of the divine message, but that he himself personally was that message. Pertaining to Islam, a critical discussion is provided of Muhammad acknowledged by Muslims as the last prophet. As far as the life of Muhammad is concerned, Van Selms ${ }^{12}$ compares him to the Biblical King David who started his life as an insignificant person, went into exile, became an esteemed statesman but eventually became subjected

8 Similar statements are also documented by Janse van Rensburg, Adrianus Van Selms (1906-1984): What does abide", 533-534.

9 Text readily available in print and on internet, e.g. http://www.heidelbergcatechism.com/pdf/lords-days/Heidelberg-Catechism.pdf.

10 Jacobus A. Naudé, Adrianus Van Selms and Willem D. Jonker. In Gesprek met Islam oor die Moslem Belydenis (Bloemfontein: N.G. Sendinguitgewers, 1974), 82-88.

11 Naudé, Van Selms and Jonker, In Gesprek met Islam, 89-96.

12 Naudé, Van Selms and Jonker, 124. 
to the coercions of multiple marriages ("harem-dwingeland"). Commenting on Islamic theology, Van Selms ${ }^{13}$ declares that the relationship between the Qur'an and the earlier Holy Books ("vroeëre Heilige Boeke") is about the same as that between the New and Old Testament. According to the Christian view (as depicted by Van Selms), the former (New Testament) is accorded a superior quality ("hoëre kwaliteit") over the Old Testament, ${ }^{14}$ by implication even replacing it. ${ }^{15}$ In a similar vein, Van Selms refers to the critical function ("kritiese funksie") of Islamic revelation as regards earlier revelations, mentioning the phenomenon of earlier Qur'anic verses substituted by later ones. ${ }^{16}$ It should, however, be noted that in the Muslim view Jesus in fact affirmed the Old Testament. ${ }^{17}$

Van Selms" "Conversation with Islam" is concluded with a chapter in which he provides a perspective on Muhammad as observed from Christian viewpoint. Reference is made to Christian polemical literature and the early history of Christian-Muslim contact. In Van Selms' view Christian theology and preaching was deficient during the early period of Islam. He is critical of the crusades and the attacking of Muhammad in European literature. Van Selms ${ }^{18}$ then decides that Muhammad should be acknowledged as "one of the great figures of humanity". Muhammad should be admired as author of the Qur'an, and as reformer of communal life among Arabic tribes. However, Van Selms declares that Muhammad has no place within Christian salvation history. For Van Selms, Muhammad is a borderline figure ("randfiguur") within church history comparable with people like Spinoza, Marx and Nietzsche who influenced church history. Van Selms then expresses the opinion, "For reasons concealed from us, it pleased God to chastise his church with the words and conduct of these people." Applied to Muhammad and the Muslims, Van Selms' theodicy is a reminder of a comparable statement in $8^{\text {th }}$ and $9^{\text {th }}$ century Christian-

\footnotetext{
13 Naudé, Van Selms and Jonker, 129-130.

14 Cf. Hebrews 8:6.

15 Cf. Hebrews 10:9, "He [Jesus] sets aside the first [covenant] to establish the second [covenant]".

16 Cf. Surah 16:101 in the Qur'an, “And when We [i.e. Allah] substituted (baddalnā) a verse in the place of a verse ...".

17 Cf. Surah 5:46, "And We sent in their footsteps [i.e. those of the Old Testament prophets] Jesus, the son of Mary, confirming (musaddiqan) that which came before him in the Torah; and We gave him the Gospel ... confirming that which preceded it of the Torah ...".

18 Naudé, Van Selms and Jonker, 143-144.
} 
polemical texts. Sidney H, Griffith ${ }^{19}$ quoting from Hoyland ${ }^{20}$, for example, mentions a sermon of the Patriarch Sophronius (dated between 634 and 637) in which he refers to the Saracens ${ }^{21}$, "who, on account of our sins, have now risen up against us unexpectedly and ravage all with cruel and feral design, with impious and godless audacity".

\section{RESPONSE TO MUSLIM CULTURE}

In his books, especially those focusing on Jerusalem and Northern Israel, Van Selms expresses his appreciation for the Muslim material culture, and customs related to those practised in Old and New Testament times.

\section{$1 \quad$ Muslim material culture}

Van Selms's 1968 study $^{22}$, discussing the history of Jerusalem throughout the centuries, from before King David to General Dayan, dedicates its $16^{\text {th }}$ chapter to "the most beautiful sanctuary". In it, Van Selms discusses the period of Arabic-Islamic rule in Jerusalem, commencing with the city having been conquered without any reported bloodshed in 637 during the reign of the second caliph Umar. Special attention is given to subsequent building activities. Caliph Umar is credited for erecting a wooden mosque at the southern end of the terrace where the Israelite temple was situated. Van Selms states:

The [said] site is associated with the "Farthest House of Prayer" (Uiterste Bedehuis [al-Masjid al-'Aqșā]]) regarding which the prophet spoke in the seventeenth chapter [verse one] of the Koran. Later the plain wooden structure was replaced by a brick mosque, which was often, after an earthquake, repaired and rebuilt and is presently still called the Aqsa, "the Farthest House of Prayer", the main mosque in Jerusalem. ${ }^{23}$

Van Selms ${ }^{24}$ also refers to an additional structure, wrongly called the mosque of Umar in western literature, built by the Umayyad caliph Abd alMalik. It was built over a rock on the terrain of the temple, where the Jewish Holiest of Holiest (part of the original temple) had stood. It was meant as an

19 Sidney H. Griffith. The Church in the Shadow of the Mosque, Christians and Muslims in the World of Islam (Princeton: Princeton University Press, 2008), 25, cf. 26.

20 Hoyland, Robert G. Seeing Islam as Others Saw It: A Survey and Evaluation of Christian, Jewish and Zoroastrian Writings on Early Islam (Princeton: Darwin Press, 1997), 69.

21 I.e. Muslim Arabs; literally 'plunderers', cf. the Arabic term sāriqīn.

22 Adrianus Van Selms. Jeruzalem deur de Eeuwen een, van vóór Koning David tot Generaal Dayan (Baarn: Hollandia, 1968).

23 Van Selms, Jeruzalem deur de Eeuwen heen, 202.

24 Van Selms, Jeruzalem deur de Eeuwen heen, 206. 
alternative ("surrogaat") for the Kaaba at Mecca where Abdullah ibn Zubair at that time had established a competing caliphate.

The said building is eight-cornered, fifty metres in diameter with two concentric series of pillars with two domes, the one resting on the inside series of pillars and the other upon the first, so that the visitor is treated with the impression that the 33 metre high top dome is suspended in the air. Van Selms observes:

The [so-called] Dome on the Rock ("Rotskoepel"), repeatedly afflicted by earthquakes but again repaired without damaging the total impression [created by the complex], is one of the most impressive religious buildings. The Christian churches in Jerusalem cannot equal it. The absence of statues and paintings [in the dome on the rock] is refreshing ("een verademing") and the gold on blue inscriptions [protesting against the doctrine of the divinity of Christ, e.g. Q. $17: 111$ and $4: 171]$ join harmoniously the architectural lines. ${ }^{25}$

In the said 1968 study, Van Selms also draws attention to the rebuilding of the dilapidated walls of Jerusalem by the Ottoman emperor Suleiman the Great (1520-1566). The said walls were built upon the foundation of the walls dating from the time when the Romans were masters of Jerusalem. Within the period of Turkish rule seven of the present city gates were also erected.

Van Selms mentions that during the British Mandate of Palestine one could walk on the top of the walls of Jerusalem, on their inside. He then describes (1968:230) the view one had:

The wall is built of limestone, sawn and broken [from rocks] in stonequarries and caves in the vicinity. Initially the stone is grey-white, but after some centuries a yellow tint appears. If sun rays reflect [on them] within the necessary gradient, the whole wall creates the appearance of being golden. I remind myself of one late afternoon in January, leaving the Rockefeller museum [located in East Jerusalem] at the north-eastern side, [that] the sun setting in the west was shining softly upon the wall with such a perfect gloss it was as if the vision of John (Revelations 21:18 [describing the new eschatological Jerusalem]) was already fulfilled: 'The wall was made of jasper, and the city of pure gold, as pure as glass.'

If one tries to add meaning to the experience so unrepeatable ... spontaneously a Christian Latin ['Urbs Syon aurea', golden city Zion] or a Jewish Hebrew song ['Jeroesjalajim sjel zahav', Jerusalem of gold] comes to mind [giving them new and concrete meaning]. But that [remembering of these songs] occurs [strangely enough] when we look at a Turkish, Islamic edifice, the wall of Suleiman; and within 
the wall there is no more beautiful sanctuary than the Dome of the Rock, similarly a building of Islam. Fairness ("billikheid") would therefore require that we now [at this occasion] should sing an Arabic or Turkish song, in any case an Islamic one in praise of the golden Jerusalem, but I don't believe that such a song exists. I do indeed know an Arabic folk-song, which always greatly impressed me because of its first line:

'Nothing is as red as the flowers of Jerusalem'.

And at the end of January you can in fact find beautiful red anemones on the mountains. But that [sight] touches one in a whole different way than the delight as regards the Holy City with her buildings. ${ }^{26}$

In all three examples, Van Selms' admiration for Muslim, particularly Turkish, building activities, is striking. It is worth noting the comparisons drawn in the second and third excerpts. The Dome of the Rock is contrasted with Christian churches by Van Selms, leaving no doubt as to where his preference lay. In the case of the walls of Jerusalem, the comparison is not evaluative but appreciative. The walls of Jerusalem, when reflecting the sun, are evocative of the eschatological Jerusalem found in Revelations 21:18. His impressions and emotions at viewing the are celebrated, in typical Van Selms fashion ${ }^{27}$, through recalling a Christian, Jewish and eventually an Arab song. Muslim structures on Jewish temple terrain rule out associating the view with a Biblical song. However, Van Selms' wonder at the structures could perhaps be related to a similar feeling of awe documented in Psalm 48, which sings in praise of the "city of God ... beautiful in its loftiness".

\section{Muslim customs}

Two specific customs to which Van Selms refers in his work are the traditional Muslim manner of prayer, and the way Fridays are spent. Both are regarded as exemplary, but in different ways.

While looking for the grave that was associated with the biblical prophet Jonah, during his journey by foot through Northern-Israel, Van Selms mentions a visit to a mosque in the town Mesjhed. He writes:

If you go to the highest part of the town, you will soon come to the mosque, recognisable by her two domes. It is an ordinary looking ("sober") building without a minaret. You are welcome to enter, providing you leave your shoes in the porch. Be not afraid that your shoes will be stolen; it never happens. Walking on socks we enter

26 Van Selms, Jeruzalem door de Eeuwen heen, 229-230.

27 Cf. Janse van Rensburg, "Adrianus Van Selms (1906-1984): What does abide", 543. 
through the right hand doorway the place of prayer. Mats are lying on the floor, and further away, closer to the prayer niche ("gebedsnis") indicating to believers the direction to Mecca, (lie) carpets. Here you can see, particularly on Fridays at twelve, how men in biblical times performed prayer. Only in Islam, not in Judaism and Christianity, has the biblical posture of prayer been preserved: first standing, then kneeling, then touching the ground with the forehead. Likewise prayed Abraham (Genesis 17:3), Moses (Numbers 16:22), the Israelite people (Exodus 12:27) as well as Jesus (cf. Luke 22:41 with Matthew 26:3928). It is strange that this posture during prayer has been completely neglected; perhaps more than strange, disquieting ["verontrustend"]; because only [those with an attitude of] the utmost superficiality ["oppervlakkigheid"] can allege that posture during prayer is only a superficial matter. Who knows how much blessing we have lost by no longer praying in the biblical posture?

We leave the place of prayer with deep respect for Islam and the hope that at God's [predetermined] time once again a true ("wezenlik") dialogue with the followers of Mohammed may come. ${ }^{29}$

Even earlier in his academic career, in a book giving an account of the contrasting views on the celebration of the Christian Sunday, Van Selms remarks that early gentile (i.e., non-Jewish) Christians had the custom to hold their religious gathering on that day. The first day, for them, thus did not carry the character of a day of rest, as was the case with the Jewish Sabbath. He continues:

It [the Sunday] was rather comparable with the Mohammedan Friday; this day is known [in Islamic context] as "the day of gathering", the day on which members of the [Muslim] congregation convene to hear a sermon (on other days of the week only the customary prayer takes place) without being under obligation not to do any work. ${ }^{30}$

In the above examples, Van Selms firstly focuses on a specific gesture of prayer, i.e. falling with the face to the ground and praying. There are of course other gestures as well. ${ }^{31}$ The presumption of Van Selms is that gesture should express an attitude of submissiveness and humility before God. ${ }^{32}$ Furthermore,

28 Matthew 26:39: "he (Jesus) fell with his face to the ground and prayed".

29 Adrianus Van Selms. Levend Verleden, Een Zwerftog door Noord-Israel (Nijkerk: Callenbach, 1967), 96.

30 Adrianus Van Selms. De Zondag tussen Farizeïsme en Libertinisme (Nijkerk: Callenbach, 1937), 15.

31 Ceremonial Muslim prayer includes various gestures, e.g. standing [during the afternoon prayer] (Surah 2:238), preceded by obligatory ritual washing (Surah 5:6).

32 According to Surah 23, "They who are during their prayer humble (or submissive, kašūna; verse 2) ... They are the inheritors [of Paradise] ('al-wāri'ūna; verse 9). 
Muslim prayer is ideally performed five times a day, one of them round about midday each day. It is to this prayer that the quoted example refers.

Secondly, and related to the celebration of Sundays, it should be borne in mind that at the prescribed the hour of prayer on Fridays, all business activities should be put on hold by Muslim believers. ${ }^{33}$

\section{REFERENCES TO ISLAM IN VAN SELMS'S BIBLICAL COMMENTARIES}

In his Biblical commentaries Van Selms at times draws attention to an Islamic tradition, custom or concept. Three examples, pertaining to Genesis 3:1. 30:15 and Ezra 10:11, will be discussed.

\section{Genesis 3:1}

Van Selms ${ }^{34}$, for example, during the discussion of Genesis 3:1 mentions a tradition recounted by al-Tabari (839-923).

Genesis 3:1 states (NIV translation):

Now the serpent was more crafty than any of the wild animals the LORD God had made. He said to the woman [Eve], "Did God really say, 'You must not eat from any tree in the garden'?"

Van Selms inter alia comments:

Regarding the question, how the snake could speak, the writer [of Genesis 3:1] does not concern himself; he is interested in more essential things. ${ }^{35}$ Later [New Testament] exegesis identified the snake with the devil (Revelations 12:9; 20:2). Curious is the tradition, the Muslim historian at-Tabari (838-922) recounts: the devil seated himself in the mouth of the snake and so got past the angel guarding at the entrance of the garden. Firstly he also spoke from the mouth of the snake; later he appeared himself. ${ }^{36}$

The account ascribed to al-Tabari (838-922) by Van Selms characterises him as a "Muslim historian." Al-Tabari is indeed known for his historical

33 Cf. Surah 62:9.

34 Adrianus Van Selms. Genesis deel 1 (Nijkerk: Callenbach, 1967), 64.

35 According to Claus Westermann. Genesis 1-11, a Commentary, trans. John J. Scullion (Minneapolis: Augsburg Publishing House, 1984), 238, "The animal that talks is characteristic of the tale or fable. By resuming this fairy tale trait the narrator points the way into the realm of the tale or fable."

36 Van Selms, Genesis deel 1, 64. 
chronicle titled, "History of the Prophets and Kings" ${ }^{37}$, and for his monumental commentary on the Qur'an ${ }^{38}$.

Van Selms does not identify his source, which was most probably secondary. Even the latter is not specified.

Some elements of the version of the snake episode ascribed to al-Tabari can, however, be found in his commentary on Q. 7:20 relating Satan's communication with Adam and his wife. In it a tradition is reported on ultimate authority of Ibn 'Abbas, a cousin of Muhammad.

Allah's enemy, Iblis ${ }^{39}$, presented himself to all the animals of the earth [to determine] which one would carry him until he could enter Jannah and speak to Adam and his wife. However, all the animals refused him this until he spoke to the snake. And he said to it: You have been kept back from mankind ${ }^{40}$. [But] you are indeed under my protection if you bring me into Paradise. So the snake put him between two of his incisors. Then he entered with him. And he [Satan] spoke to the two of them [namely Adam and his wife] from within the snake.

Satan's conversing with Adam and his wife reported in Q. 7:20-1 occurs after Satan's falling out of favour with Allah and being expelled (Q. 7:18) from Paradise. However, Satan reappears on the scene addressing the initial couple on earth in Paradise (Q. 7:20). This seeming incongruity leads to speculation how he could have managed to re-enter Paradise. The account ascribed to al-Tabari provides one answer. The contents of the Tabari account quoted by Van Selms, however, has strong affinities with the Biblical version found in verses following Genesis 3:1. The Qur'anic version does not visualise Satan in the form of a snake. It (the Qur'an) simply states, "But Satan whispered to them ...". Furthermore, the Qur'anic version does not make reference to an angel guarding at the entrance of the garden. The Biblical account introduces the theme of "cherubim and a

37 Printed edited Arabic versions by Michael, J. Goeje (ed.), Tārīkh al-rusul wa-almulūk. (Leiden: Brill, 1879-1901) comprising 13 volumes with two extra volumes containing indices, introduction and glossary. Cf. also Mohammed Hamidulla (ed), Tarikh Al-Tabari /par Al-Tabari Abi Ja 'far Mohammed Ibn Jarir Al-Tabari (Dar alMaaref, 1967). Translations of various parts were published in separate volumes, e.g. Bosworth, Clifford E. (ed), The History of al-Tabari. Vol. XXXIII. Storm and Stress along the Northern Frontiers of the Abbasid Caliphate. The Caliphate of al-Mu'tas'im A.D. 833-842/A.H. 218-227, Translated and Annotated by C.E. Bosworth (Albany, New York: SUNY Press, 1991).

38 Printed Arabic edition titled al-Tabarī Muhammad b. Jarīr. Jāmi ‘ al-bayān 'an ta 'wīl al-Qur' ān, 30 volumes (Cairo: Muștafā al-Bābī al- Ḥalabī, 1961).

39 Iblis, reminding of the Greek diabolos (cf. Matthew 4:5), is an alternative name for Satan (cf. Q. 2:268) in the Qur'an.

40 Literally, "offspring ('ibn) of Adam". 
flaming sword flashing back and forth to guard the way to the tree of life" only after mentioning Adam and Eve's expulsion from the Garden of Eden (Genesis 3:24). Al-Tabari's account may therefore echo some Jewish tradition extant in Arabia at the time of his writing his commentary, or earlier. ${ }^{41}$

Using an Islamic parallel by Van Selms is admirable. However, important aspects as regards the Qur'anic version versus the Biblical account could have enhanced the commentary on the Genesis account.

Firstly, concerning similarities, the Qur'anic account (as does the Biblical) mentions the aspect of nakedness, but refers to it as the initial objective of Satan. The latter whispered to the first couple, "to make apparent to them that which was concealed from them of their private parts" (Q. 7:20). Similar to the Biblical account (Gen. 3:6-7) the couple become aware of their nakedness $(\mathrm{Q}$. $7: 22)$ after eating from the forbidden fruit.

Secondly, there are explicit differences. Contrary to the Biblical version, which ends in an anti-climax with the cursing of the man and his wife (Genesis 3:14f), the Qur'anic account mentions man and woman's asking Allah for forgiveness, and receiving it (Q. 7:23f). And as proof of Allah's mercy, man and his wife are told, "And for you on earth is a place of settlement and enjoyment".

\section{Genesis 30:15}

Van Selms, furthermore, makes use of an Islamic custom when elucidating the context of Genesis 30:15.

The said verse (Genesis 30:15) reports a dialogue between the two wives of Jacob. Negotiations are described during which Rachel, who was the beloved spouse of Jacob, offered her sister Lea the opportunity to sleep with Jacob in exchange for mandrakes.

The situation pictured here is that of a husband favouring one wife above the other within a multiple marriage. This leads to negligence of the other wife. In the case of Jacob, however, the neglected wife, Leah, bore him children, while the beloved wife, Rachel, could initially not conceive. Jacob nevertheless cohabited with Rachel, while Leah had to negotiate with Rachel for an opportunity to sleep with their mutual husband.

41 In support of this view is a Jewish tradition quoted by al-Tabari immediately after the one referred to above (i.e. the speaking of the snake). In the second tradition it is said that the snake used to walk on four legs, but that Allah caused it [afterwards] to move on its belly. A similar tradition is documented by Targum Pseudo-Jonathan. Cf. Israel Drazin and Stanley M. Wagner, Onkelos on the Torah, Understanding the Bible Text (Jerusalem: Gefen, 2006), 405. 
In Genesis 30:14 and 15 such an occasion is recounted where Leah in return for "mandrakes ( $d \bar{u} d \bar{a}$ ' $\bar{\imath} m)$ ", believed to have aphrodisiac properties, was allowed to spend a night with Jacob. No active role in decision-making is ascribed to Jacob. The Bible (Genesis 30:16) states that Leah simply informed

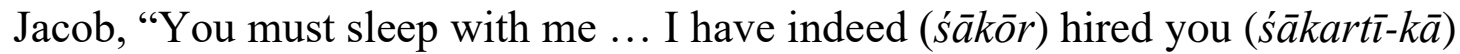
with my son's mandrakes". Jacob, in response (according to the Bible), "slept with her that night". ${ }^{42}$

Van Selms offers two comments: Firstly: Whoever was married to more than one wife had to sleep with each wife in turns, cf. Exodus 21:10 and the Mohammedan code of conduct ["gedragslijn"]. Secondly: Jacob had become the fancy-man ("gigolo") of his wives. ${ }^{43}$

Exodus 21:10, a law from the Torah, codified much later than the time of Jacob, states:

If he marries another woman, he must not deprive (lo' ${ }^{\prime}$ yigrā'; literally, 'reduce [from]'; cf. Exodus 5:8,19) the first one of her food, clothing and marital rights ('ōnōt, pl. of 'ōnāh).

The stated legislation echoes common Semitic requirements ${ }^{44}$, but the contexts of Genesis 30:14f and Exodus 21:10 do not agree. In Exodus the "he" who marries refers to a person who has been given a slave-girl in marriage and then marries another woman. Religious law now stipulates that the husband should not materially and sexually deprive the first slave wife. As a matter of fact, Exodus 21:11 determines that if the said two privileges are not provided to the slave wife, "she is to go free, without any payment of money".

Multiple marriage did occur but was not encouraged in the early IsraeliteJudaic society, and was thus not formally regulated. The intention of Van Selms may simply have been to allude to the existence of some common law pertaining to the equal treatment of multiple wives.

42 'Sleeping' of course implied intercourse, eventually leading to the birth of Issachar. Furthermore, the deal between Rachel and Leah also allowed the latter constant cohabitation with Jacob, with two further children, a son Zebulon and a daughter Dinah as the result. The two sons, Issachar and Zebulon are highly rated in Jewish tradition. Rabbi Levi comments, 'Issachar studied the Torah while Zebulon went out to the sea and provided Issachar with sustenance'. Cf. Harry Freedman, Midrash Rabbah, volume 2, translated by Rabbi Dr H. Freedman (New York: The Soncino Press, 1983), 665.

43 Adrianus Van Selms, Genesis deel 2 (Nijkerk: Callenbach, 1967), 105.

44 Cf. Wolfram von Soden, Akkadisches Handwörterbuch (Wiesbaden, Germany: Harrasowitz, 1965-1981), 385a; and Hebraïsches und Aramaïsches Lexicon zum Alten Testament, Dritte Auflage (Leiden: Brill, 1995), 809. 
Of relevance to this paper, is the general reference to the Old Testament (Exodus 21:11) in Van Selms' commentary being augmented by an unspecified mentioning of a similar "Mohammedan code of conduct".

Marrying up to four wives was officially accepted since early Islam (Q. $4: 3$ ), and thus under judicial control by various laws that were reminders of the conduct stipulated in Exodus 21:10. The underlying principle is ordained in Q. $4: 129$.

Firstly, it takes as a basic reality that inequality would exist within a multiple marriage, stating:

You would never be able to be equal ( $l \bar{a}$ ' $t a$ ' $d i l \bar{u})$ between wives, even

if you should strive (or 'desire', law haraștum) [to do so].

Secondly the Qur'an advises the amending of the situation, at least formally:

So do not incline (lā' tamìlū) completely (literally, 'all inclination', kulla 'l=maili) [towards one] and leave another (fa-tadarü-ha $[w-\underline{d}-r$ I impf.) hanging (i.e., 'as in suspense', $k a$-'l-mu 'allaqati])

The advice given does not mention detail regarding man's responsibility. However, Q. 4:34 refers to a husband's general obligation toward the maintenance of his wife.

Leaving a second wife in suspense is not permissible in Islam. Husbands have, according to the Qur'an, two options, namely to set right the relationship (Q. 4:129b) or to separate from the wife he is neglecting. The latter option, divorce, echoes Exodus 21:11, although it should be borne in mind that the situation of a slave-girl wife is not reflected in the Qur'an.

Examples of multiple wives and the intrigues involved are abundant in Islamic literature. The Prophet Muhammad himself was husband to several wives. Tradition reports that the Prophet loved ' $\overline{\mathrm{A}}$ 'ishah above his other wives "although he maintained strict equality between them in the tangible matters of financial support and time spent with each" ${ }^{\text {. }}$.

\section{Ezra [10:11]}

In 1935 Van Selms's earliest Biblical commentary, namely on Ezra and Nehemiah, was published in the series "Text and Interpretation Practical Biblical Exposition" (Tekst en Uitleg Praktische Bijbelverklaring).

45 Seyyed H. Nasr (ed.), The Study Qur'an, a New Translation and Commentary (New York: HarperCollins, 2015), 251a. 
The biblical books Ezra and Nehemiah focus on the period 537 to 432 $\mathrm{BCE}$ in Israelite history, when groups from the Jewish nation were permitted by the Persian authority to return to Palestine and reorganise themselves. At that time, an ethnically and religiously mixed local population inhabited Jerusalem and its vicinity. In response, Ezra the priest ordered the Jewish men involved to separate themselves from the people around them and from their foreign wives (Ezra 10:11). The presumed argument was seemingly that socialising, and in particular marriage, to non-Jews would lead the Israelites astray. ${ }^{46}$

In the introduction to the early commentary discussing the religious meaning of the books within their time frame, Van Selms ${ }^{47}$ remarks that the whole period concerned was characterised by a struggle for the purity of "the holy seed" and its religious worship. He continues:

Israel after the exile was just as much a [religious] congregation as a nation. In this time [i.e. the Ezra period] we find in Judah one of the remarkable communities often found in the Middle East, closed communities with both a national and religious basis. Arabic has its own word [to typify such a community], namely umma which we could render in turn as "congregation" (gemeente) or "nation". Present [1935] parallels are the Druse people and the Jezidies.

The two groups of people referred to by Van Selms both practise a syncretistic religion of which only some aspects can be related to Islam. ${ }^{48}$ Both the Druse people and Jezidies can be identified in terms of ethnic and geographical features, but are predominantly religiously defined. They are only remotely associated with Islam.

It is notable that to these communities, extant in the Middle East nearly hundred years ago, as well as the Ezra-envisaged Jewish society, Van Selms applies the Arabic concept 'ummah which, according to him, may be used in both a religious and a political sense.

46 Deuteronomy 20:18 and Exodus 34:16. A similar situation is sketched in Nehemiah 13:23-29. In the latter case a drastic response (physical violence) is reported, but no mention is made of forced divorce from present wives. According to David J.A. Clines, Ezra, Nehemiah, Esther (Grand Rapids: Eerdmans, 1984), 246, "As for the propriety of their methods, some may find it hard to choose between the massive exertion of moral pressure of Ezra and the direct physical violence of Nehemiah!"

47 Adrianus Van Selms, Ezra en Nehemia (Groningen: J. B. Wolters' UitgeversMaatschappij, 1935), 21-22.

48 Discussions of the Druze and Jezidies (Yazidis) people can respectively be accessed at https://en.wikipedia.org/wiki/Druse and https://en.wikipedia.org/wiki /Yazidis\#Religious\%20beliefs.]. 
Seen in isolation, the said term, however, has many connotations which can be demonstrated by reviewing its utilisation in the Qur'an. ${ }^{49}$

The concept has a predominantly religious connotation, defining a community, unified through the common belief in One God. ${ }^{50}$ Furthermore, being a religiously determined society implies having an esteemed status and being exemplary ${ }^{51}$, with an ethical responsibility to "enjoin what is right (ta'murüna bi-'l-marüfi), and forbid what is wrong. ${ }^{52}$ (wa-tanhawna 'an 'almunkari)."53 Ideally, brotherhood and harmony should exist within the community. ${ }^{54}$ Indeed, drawing from this, the Muslim community in a broader or narrower sense can be defined as a "collective of believing individuals who have moral obligations to the community as a whole and to each of its members as well as to themselves" "55. However, the appellation 'ummah can refer to any nation usually within a religious context, ${ }^{56}$ including Jews. ${ }^{57}$

Preserving the religious identity of the newly established Muslim community ('ummah) was of cardinal importance in early Islam. Converts were not ordered to divorce their wives, but restrictions as regards intermarriage with mušrikāt and mušrikūn are recorded in the Qur'an. ${ }^{58}$ The said terms apply to women and men respectively, deemed to be polytheists.

\section{E DISCUSSION AND ADDITIONAL EXAMPLES}

As part of the contextualisation of statements pertaining to Islam within the literary contribution of Adrianus van Selms, the article focused on a selection if

49 Cf. references and commentary provided by Seyyed H. Nasr (ed.), The Study Qur'an and Qur'anic translations by Șaheeh International, The Qur'àn, Arabic Text with Corresponding English Meanings (London: Abulqasim Pubishing House, 1997).

50 Surah 23:52 states, "And indeed this, your community ('ummatu-kum), is one community ('ummatun wāhidatun), and I am your Lord (rabbu-kum), so fear me ( $f a$ 'ttaqū-ni).

51 Surah 23:52 states, "You are the best nation (kuntum kaira 'ummatin), produced [as an example] for mankind ('ukrijat li-l-nāsi)."

52 Surah 3:110.

53 Surah 3:110.

54 This important aspect is underlined in Surah 49:10, "Believers are but brothers ('ihwatun), so make a settlement ( $f a$-'așlihiu) between your brothers."

55 Maria, M. Dakake, "Qur'anic ethics, human rights, and society”, in Nasr, Seyyed H. (ed.), The Study Qur'an, a New Translation and Commentary, 1785.

56 Surah 10:47 states, "And for every nation (wa-li-kulli 'ummatin) is a messenger (rasūlun)".

57 Surah 7:159, "And among the people of Moses (wa-min qawmi musâ) is a community ('ummatun) which guides by truth (yahdüna bi-'l- haqqi) and by (bi-hi) it establishes justice (ya 'dilüna)".

58 Surah 2:221. 
excerpts. Not all Van Selm's academic endeavours could be accessed. There may be more references to Islam. Furthermore, among the available material not all allusions to Islamic sources have been included. Lexical and grammatical use of Arabic sources have not been considered. Among available examples some interesting material may be found, for instance the 1979 discussion of Van Selms regarding the meaning of the concepts sijjin and sijjil in the Qur'an. ${ }^{59}$

Van Selms argues that both terms are derived from the Latin word signu, 'seal' (stamp impression), and its diminutive sigillion. This leads him to interpret the phrase hijärah min sijjill, referred to in the Qur'anic description (Surah 15:74) of the destruction of the raining of stones on the city as punishment for Lot's cocitizens as "stones, namely each of them a stamp impression". According to Van Selms, the allusion is to the thousands of inscribed bricks among the remains at the site of the procession-street of Marduk at Babylon. As in the case of the elucidation of Arabic-Afrikaans catechism, su'āl wa-jawāb (question and answer), an ultimate Babylonian-Assyrian origin is thus claimed for the Qur'anic phrase.

The contributions of Van Selms pertaining to Islam discussed here lead to the conclusion that the study of Islam was not his primary focus. Even the 1979 and 1951 publications do not represent in depth investigations into the Islamic religion, but rather demonstrate an attempt to transliterate and translate ArabicAfrikaans texts for the benefit of a language-orientated local community. Van Selms's 1974 contribution to In Conversation with Islam as Regards the Muslim Confession of Faith contains interesting statements and reveals a more penetrating look at the topic under focus here. However, being part of a document that propagates a pro-Christian point of view, Van Selms' commentary here displays some bias in his portrayal of Islam and Muhammad.

Nevertheless, in all his works that have been considered, a deep respect for Islam is visible. Van Selms even openly articulates his admiration for Islamic material culture and customs. He warns against attempts to degrade and belittle Islam.

However, his positive non-confrontational point of view also has a counter-side. This may be illustrated in his rendering of the Afrikaans-Arabic text of at least in one of the items of the 1951 published catechism. ${ }^{60}$ Van Selms, possibly fearing that the literal translation may sound crude, translates the answer to the said item in an interpretative way. ${ }^{61}$

59 Adrianus Van Selms, "sijjin and sijjīl in the Qur'an", Die Welt des Orients 9 (1979):99-103.

60 Van Selms, 'n Tweetalige (Arabiese en Afrikaanse) Kategismus, 51-52.

61 Van Selms, 'n Tweetalige (Arabiese en Afrikaanse) Kategismus, 50, transliterates the Arabic-Afrikaans text as: "[a] die biwaisein fan firstant oep die sifat is die karai fan 
In question 6 of the catechism it is asked, "What is the proof of the existence of Allah [the first of his twenty characteristics (sifät)]?" The suggested answer in the text (translated literally) is,

a) The proof of the mind is the getting of the creation;

b) but truly if Allah, He is most high, not must be, then there is no Allah,

c) and if there is not one Allah, then there will not be gotten anything of this creation.

Van Selms interprets the above as:

a) The reasonable proof: the existence of this creation,

b) because, if He were not found, He would be non-existing,

c) and if He were non-existing, then nothing of this creation could be found. ${ }^{62}$

Compared with the literal translation, it appears that Van Selms translates "Allah" in both lines "a" and "b" with the pronoun "He".

Problematic in lines "b" and "c" is the expression (in the literal translation above), "no Allah". The solution would have been to bear in mind the Muslim confession of faith,

là 'ilāha illāa (<in lā) 'Allāha ("[There is] no god if not Allah")

The confession, "no god if not Allah" is produced in a variant way in the catechism. Translated freely, the meaning conveyed was probably.

if Allah were not, there would be no god ${ }^{63}$ [which can only be Allah], and if there were no god" [which can only be Allah], there would be no creation.

die ghaskaapandie [b] maar waarlik es allāhu ta 'âlā nie moet wies nie dan is daar nie allāhu nie [c] en es daar nie ien allāhu ta 'âlā es nie dan sal daar nie gakarai wies nie iets fan die ghaskaapandie nie."

62 Van Selms, 'n Tweetalige (Arabiese en Afrikaanse) Kategismus, 79-80 renders the said answer in Afrikaans as: [a] "Die redelike bewys: die bestaan van hierdie skepping, [b] omdat, as Hy as nie aangetref sou word nie, Hy nie-bestaande sou wees; [c] en as Hy nie-bestaande was, dan sou daar niks van hierdie skepping aangetref kon word nie." 63 The transliteration of 'allāhu is suspect. The Arabic-Afrikaans text would probably only have written it (as customary in Arabic) with the consonants '- $l l-h$ which is rendered as Allah. It should, however, be borne in mind that the said Arabic-Afrikaans text is simultaneously a translation of an original Arabic text which perhaps had the consonants '- $l-h$ (instead of "'-ll-h) which can be rendered as $i l a \bar{h}$, i.e. "god". 
Furthermore, in Van Selms's Biblical commentaries, the allusions to Islam, whether as a tradition, custom or concept, are of a relatively general nature. In each case an alternative, more focused and elaborate utilisation of Islamic comparative sources, as suggested, would have been more apt. Nonetheless, in the final instance, a positive evaluation of Van Selms' use of Islamic comparisons needs to be recorded. Juxtaposing Biblical and Islamic material enriches, deepens and enhances the understanding of both beliefs.

\section{BIBLIOGRAPHY}

Bosworth, Clifford E. (ed), The History of al-Tabari. Vol. XXXIII. Storm and stress along the northern frontiers of the Abbasid Caliphate. The caliphate of alMu'tas'im A.D. 833-842/A.H. 218-227. Translated and annotated by C.E. Bosworth. Albany, New York: SUNY Press, 1991.

Brandel-Syrier, Mia.The Religious Duties of Islam as Taught and Explained by Abu Bakr Effendi. A Translation from the Original Arabic and Afrikaans, Edited with an Introduction and Notes. Leiden: Brill, 1960.

Clines, David J.A. Ezra, Nehemiah, Esther. Grand Rapids: Eerdmans, 1984.

Dakake, Maria, M. "Qur'anic ethics, human rights, and society". Page 1785 in The Study Qur'an, a New Translation and Commentary. Edited by Nasr, Seyyed H. New York: HarperCollins, 2015.

Drazin, Israel and Stanley M. Wagner. Onkelos on the Torah, Understanding the Bible Text. Jerusalem: Gefen, 2006.

Freedman, Harry. Midrash Rabbah. Volume 2. Translated by Rabbi Dr H. Freedman. New York: The Soncino Press, 1983.

Michael, J. Goeje, ed. Tārīkh al-rusul wa-al-mulūk, 13 volumes with two extra volumes containing indices, introduction and glossary. Leiden: Brill, 1879-1901.

Griffith, Sidney H. The Church in the Shadow of the Mosque, Christians and Muslims in the World of Islam. Princeton: Princeton University Press, 2008. https://doi .org/10.1515/9781400834020.

Hamidulla, Mohammed (ed), Tarikh Al-Tabari /par Al-Tabari Abi Ja far Mohammed Ibn Jarir Al-Tabari. Beirut, Lebanon: Dar al-Maaref, 1967

Hebraïsches und Aramaïsches Lexicon zum Alten Testament, Dritte Auflage. Leiden: Brill, 1995.

Heidelberg Catechisms (1563), http://www.heidelberg-catechism.com/pdf/lords-days/ Heidelberg-Catechism.pdf.

Hoyland, Robert G. Seeing Islam as Others Saw it: A Survey and Evaluation of Christian, Jewish and Zoroastrian Writings on Early Islam. Studies in Late Antiquity and Early Islam, 13 Princeton: Darwin Press, 1997.

Janse van Rensburg J. F. (Hans). "Adrianus Van Selms (1906-1984): What does abide. Aspects of his life and literary contribution." Journal for Semitics 26/1 (2017):504-545. https://doi.org/10.25159/1013-8471/3133.

Le Roux Jurie H. A Story of Two Ways, Thirty Years of Old Testament Scholarship in South Africa. Pretoria: Verba Vitae, 1993.

Loader, James A. “Adrianus Van Selms: responsum.” Journal for Semitics 7 (1995): 240-250.

Nasr, Seyyed H. (ed). The Study Qur'an, a New Translation and Commentary. New York: Harper Collins, 2015. 
Naudé, Jacobus A., Van Selms, Adrianus and Willem D. Jonker. In Gesprek met Islam oor die Moslem Belydenis. Bloemfontein: N.G. Sendinguitgewers, 1974.

Șaheeh International. The Qur'ān, Arabic Text with Corresponding English Meanings. London: Abulqasim Pubishing House, 1997.

Soden, Wolfram von. Akkadisches Handwörterbuch. 3 vols. Wiesbaden: Harrassowitz, 1965-1981

Van Selms, Adrianus. Ezra en Nehemia. Tekst en Uitleg Praktische Bijbelverklaring. Groningen: J. B. Wolters' Uitgevers-Maatschappij, 1935.

Arabies-Afrikaanse Studies 1. 'n Tweetalige (Arabiese en Afrikaanse) Kategismus. Mededelingen der Koninklijke Nederlandse Akademie van Wetenschappen, Afd. Letterkunde, Nieuwe Reeks, Deel 14, No. 1. Amsterdam: N.V. Noord-Hollandsche Uitgevers Maatschappij, 1951.

"The manuscript and its author". P. v-ix in The Religious Duties of Islam as Taught and Explained by Abu Bakr Effendi. A Translation from the Original Arabic and Afrikaans, with an Introduction and Notes. Edited by Mia BrandelSyrier. Leiden: Brill, 1960.

Genesis deel 1. De Prediking van het Oude Testament. Nijkerk: Callenbach, 1967.

Genesis deel 2. De Prediking van het Oude Testament. Nijkerk: Callenbach, 1967. 1967.

Levend Verleden, Een Zwerftog door Noord-Israel. Nijkerk: Callenbach,

Jeruzalem deur de Eeuwen heen, van vóór Koning David tot Generaal Dayan. Baarn: Hollandia, 1968.

Abu Bakr se 'Uiteensetting van die Godsdiens', 'n Arabies-Afrikaanse Teks uit die Jaar 1869. Amsterdam: North-Holland Publishing Company, 1979. "sijjin and sijjil in the Qur'an." Die Welt des Orients 9 (1979): 99-103.

Westermann, Claus. Genesis 1-11: A Commentary. Translated by John J. Scullion. Minneapolis: Augsburg Publishing House, 1984.

Muhammad Ashraf Ebrahim Dockrat, LANCsal, Faculty of Humanities, University of Johannesburg, PO Box 13001, Laudium, Pretoria, 0037. Email: molvi@mandla.co.za. ORCID: https://orcid.org/0000-0001-8321-6357. 